\title{
Tumor suppressor gene alterations of spontaneously malignant transformed cells from human embryonic muscle in vitro
}

\author{
XIANYAO WANG ${ }^{1,2}$, WENYU LI $^{1}$, JIAKUN ZHENG ${ }^{1}$, QIANG CHEN $^{1}$, HAIYING ZOU $^{3}$, LIAN MA ${ }^{2}$, \\ GUANGYU LIN ${ }^{2}$, TIANHUA HUANG ${ }^{2}$, GE HUANG ${ }^{2}$ and LIYE YANG ${ }^{1,2}$ \\ ${ }^{1}$ Central Laboratory, Chaozhou Central Hospital, No. 84 Huancheng Xi Road, Xiangqiao District, Chaozhou 521021; \\ ${ }^{2}$ Department of Biology, Medical College of Shantou University, Shantou 515041; \\ ${ }^{3}$ Department of Biology, Hanshan Normal College, Chaozhou 521041, P.R. China
}

Received January 5, 2010; Accepted April 6, 2010

DOI: 10.3892/or_00000892

\begin{abstract}
Recent research has shown that mesenchymal stem cells (MSCs) which were cultured for long time could transform malignantly, the transformation mechanism is not clear yet, it might be associated with the activation of oncogenes and inactivation of tumor suppressor genes. In our initial investigation, we found that the cells arising from human embryonic muscle could spontaneously transform into malignancy in vitro and we obtained 6 immortalized cell lines. In this study, polymerase chain reaction (PCR) was used to assay several tumor suppressor genes of these cell lines, and homozygous deletions within chromosomal band 9p21 including MTAP (methylthioadenosine phosphorylase), $p 16$ and $p 15$ were detected. PCR products of $p 53$ exons 7 and 8 of these novel tumor cell lines were assayed by sequencing, and the results showed high prevalence of mutations in these regions, the mutation rate reached as high as $8 \%$ in exon 7 and $14 \%$ in exon 8 , and all of them were point mutations, the intron 7 changed more significantly, including piece deletion, insertion, frameshift and point mutation, it showed almost no similarity to that of the wt p53 sequence, that was totally different from other p53 mutation data published. All the mutation sequences were identical in 6 cell lines, this suggest that there may be a common mutation mechanism and strong selective advantage in these novel tumor cell lines over long-term culture. In conclusion, our research shows that the inactivation of tumor suppressor genes may play an important role in the process of malignant transformation of embryonic muscle cells in vitro.
\end{abstract}

Correspondence to: Dr Liye Yang, Central Laboratory, Chaozhou Central Hospital, No. 84 Huancheng Xi Road, Xiangqiao District, Chaozhou 521021, Guangdong, P.R. China

E-mail: yangleeyee@sina.com

Key words: tumor suppressor gene, transformation, p53, p16, 9p21, p21, sarcoma

\section{Introduction}

The development of tumors is generally accepted to be a multistep process in which alterations in oncogenes and tumor suppressor genes play an important role $(1,2)$. The process of carcinogenesis involves the gain of oncogene activity and the loss of tumor suppressor gene function, such as $R b, p 53$ and cyclin-dependent kinase inhibitor (CDKI) family (3-5). The aberrant gene could interfere in many cell funtions, such as cell proliferation, differentiation and apoptosis. The accumulative mutations constitute the base of cell malignant transformation in gene level. The acquired capabilities of tumor cells include their ability to proliferate continuously ignoring apoptosis or growth-inhibitory signals, generating their own mitogenic signals.

At present, the reports on the malignant transformation of human cell in vitro are rare. Recent research has found that mesenchymal stem cells (MSCs) cultured for long time in vitro could lead to malignant transformation, but the mechanism is not very clear. The activation of oncogenes and inactivation of tumor suppressor genes are considered to be one of the mechanisms (6-9). We have found that human embryonic muscle cells which were cultured in vitro longterm could become spontaneously immortalized, and we obtained 6 novel malignant cell lines, this new type of cell lines were named human embryonic muscle-derived malignant transformed cells (hEMTCs). These hEMTCs could be passaged stably and showed characteristics of sarcoma in vivo (10).

Herein, we report several tumor suppressor gene alterations of hEMTCs (from 5 different genetic backgrounds) and we demonstrate homozygous fragment deletions in chromosomal bands 9p21 and extensive mutations of $p 53$ gene.

\section{Materials and methods}

Cell culture. Artificial abortive embryos were obtained from Chaozhou Central Hospital, and embryonic use was ratified by the Ethics Committee of Chaozhou Central Hospital, and the informed consent of the mother and/or their family was signed, embryos ranged from 7 to 13 weeks. Leg muscle tissue was cut into $0.5-\mathrm{mm}^{3}$ pieces, put into 24 -well plates, and 
Table I. Sequence of PCR primers.

\begin{tabular}{|c|c|c|c|}
\hline Gene & Primer sequence & PCR conditions & Product size (bp) \\
\hline p16 Exon 1 & $\begin{array}{l}\text { F: 5'-CGGAGAGGGGGAGAGCAGGCA-3' } \\
\text { R: 5'-GCGCTACCTGATTCCAATTC-3' }\end{array}$ & $95,60,72^{\circ} \mathrm{C}$, each for $1 \mathrm{~min}$ & 277 \\
\hline pl6 Exon 2 & $\begin{array}{l}\text { F: 5'-TTCCTTTCCGTCATGCCGG-3' } \\
\text { R: 5'-GTACAAATTCTCAGATCATCAGTCCTC-3' }\end{array}$ & $95,57,72^{\circ} \mathrm{C}$, each for $1 \mathrm{~min}$ & 394 \\
\hline p16 Exon3 & $\begin{array}{l}\text { F: 5'-CCCGCTTTCGTAGTTTTCAT-3' } \\
\text { R: 5'-TTATTTGAGCTTTGGTTCTG-3' }\end{array}$ & $95,58,72^{\circ} \mathrm{C}$, each for $1 \mathrm{~min}$ & 355 \\
\hline p15 Exon 1 & $\begin{array}{l}\text { F: 5'-TTTCCCAGAAGCAATCCAGGCGCG-3' } \\
\text { R: 5'-CGATCTAGGTTCCAGCCCCGATCC-3' }\end{array}$ & $95,58,72^{\circ} \mathrm{C}$, each for $1 \mathrm{~min}$ & 494 \\
\hline$\beta$-actin & $\begin{array}{l}\text { F: 5'-TGGCACCACACCTTCTACAATGAGC-3' } \\
\text { R: 5'-GCACAGCTTCTCCTTAATGTCACGC-3' }\end{array}$ & $95,59,72^{\circ} \mathrm{C}$, each for $1 \mathrm{~min}$ & 396 \\
\hline p53 Exon (7-8) & $\begin{array}{l}\text { F: 5'-AGGTTGGCTCTGACTGTACC-3' } \\
\text { R: 5'-CTTGTCCTGCTTGCTTACCTC-3' }\end{array}$ & $\begin{array}{c}95^{\circ} \mathrm{C} 1 \mathrm{~min}, 57^{\circ} \mathrm{C} 1 \mathrm{~min}, \\
72^{\circ} \mathrm{C} 1.5 \mathrm{~min}\end{array}$ & 610 \\
\hline MTAP Exon 2 & $\begin{array}{l}\text { F: 5'-ATTGGAATAATTGGTGGAACAGGC-3' } \\
\text { R: 5'-CCAGCAACAGAATGAGAAGTGAT-3' }\end{array}$ & $95,57,72^{\circ} \mathrm{C}$ each for $1 \mathrm{~min}$ & 341 \\
\hline MTAP Exon 3 & $\begin{array}{l}\text { F: 5'-CAGTCTACCATCAGAGTTCCC-3' } \\
\text { R: 5'-TTGCAAGGAGGACGCAAT-3' }\end{array}$ & $95,57,72^{\circ} \mathrm{C}$ each for $1 \mathrm{~min}$ & 342 \\
\hline MTAP Exon 4 & $\begin{array}{l}\text { F: 5'-CTCTAGGAGAAAACAGTTGGTG-3' } \\
\text { R: 5'-GACCAGCTACAATAGCCTAAAG-3' }\end{array}$ & $95,57,72^{\circ} \mathrm{C}$ each for $1 \mathrm{~min}$ & 275 \\
\hline MTAP Exon 5 & $\begin{array}{l}\text { F: 5'-GACCTAGATAAAGTTGACTC-3' } \\
\text { R: 5'-TACACCTTCCAGAAAGACTA-3' }\end{array}$ & $95,57,72^{\circ} \mathrm{C}$ each for $1 \mathrm{~min}$ & 220 \\
\hline MTAP Exon 6 & $\begin{array}{l}\text { F: 5'-AGTTGTGCATGTGCTAGTAT-3' } \\
\text { R: 5'-ACCCATGCTATATGTGCTTA-3' }\end{array}$ & $95,57,72^{\circ} \mathrm{C}$ each for $1 \mathrm{~min}$ & 328 \\
\hline MTAP Exon 7 & $\begin{array}{l}\text { F: 5'-AGTTCTAGTAACCTCCAGTG-3' } \\
\text { R: 5'-CTACAGACATGCCTGATTGT-3' }\end{array}$ & $95,57,72^{\circ} \mathrm{C}$ each for $1 \mathrm{~min}$ & 195 \\
\hline p21 (RT-PCR) & $\begin{array}{l}\text { F: 5'-CAGGGGACAGCAGAGGAAGA-3' } \\
\text { R: 5'-GGGCGGCCAGGGTATGTAC-3' }\end{array}$ & $95,59,72^{\circ} \mathrm{C}$ each for $1 \mathrm{~min}$ & 335 \\
\hline p53 (RT-PCR) & $\begin{array}{l}\text { F: 5'-ACCACCATCCACTACAACTACAT-3' } \\
\text { R: 5'-GCAAGCAAGGGTTCAAAGAC-3' }\end{array}$ & $95,57,72^{\circ} \mathrm{C}$ each for $1 \mathrm{~min}$ & 589 \\
\hline
\end{tabular}

cultured in Dulbcco's modifed Eagle's medium (DMEM) (Gibco) containing 10\% FCS (Lanzhou Minhai Bio., Co.), $100 \mu \mathrm{g} / \mathrm{ml}$ penicillin, $100 \mu \mathrm{g} / \mathrm{ml}$ streptomycin and $2 \mu \mathrm{g} / \mathrm{ml}$ fluconazole in a $37^{\circ} \mathrm{C}$ humidified, $5 \% \mathrm{CO}_{2}$ air. When cultured cells became confluent, $0.25 \%$ trypsin with $0.02 \%$ EDTA was used for passage. After culturing for 4-7 months, the embryonic muscle-derived cells spontaneously transformed in 6 cell lines, and they came from 5 different genetic backgrounds ( 5 embryos). These hEMTCs could be passaged stably and immortalized. They were named MS0812, MS0504, M3, M4, M5B and M5C, respectively. M5B and M5C were from the same embryo but transformed malignantly in different culture time. The characteristics of line MS0812 was described clearly in our previous report (10). MS0504, M3, M4 and M5C could lead to fibrosarcoma in nude mice. M5B could lead to fibrosarcoma and rhabdomyosarcoma in nude mice which was confirmed by pathology (data not shown).
PCR for $p 16, p 15$, MTAP and $p 53$. Genomic DNA was isolated from hEMTCs using a genomic DNA isolation kit (Universal Genomic DNA Extraction Kit Ver. 3.0, Takara Biotechnology Dalian Co., Ltd.) according to the manufacturer's instructions. The primers for PCR were synthesized in Shanghai Sangon Biological Engineering Technology \& Services Co., Ltd. PCR was performed for exons 1-3 of the p16 (CDKN2A), exon 1 of p15 (CDKN2B), exons 2-7 of MATP (methylthioadenosine phosphorylase), exons 7-8 of p53 in a KP-TC48 thermal cycler (Hybribio Ltd.). PCRs were carried out in $10 \mathrm{mM}$ Tris $(\mathrm{pH} 8.6), 50 \mathrm{mM} \mathrm{KCl}$, $1.5 \mathrm{mM} \mathrm{MgCl}_{2}, 0.4 \%$ DMSO, $0.2 \mathrm{mM}$ dNTPs, $0.4 \mathrm{mM}$ each primer, $50 \mathrm{ng}$ of genomic DNA, and 5 unit of Taq polymerase (Takara Taq ${ }^{\mathrm{TM}}$, Takara Biotechnology Co., Ltd.) per $50-\mu 1$ reaction. The PCR conditions and primer sequences are shown in Table I. Primers for $\beta$-actin were used as a positive control for the presence of DNA. Electrophoresis of 

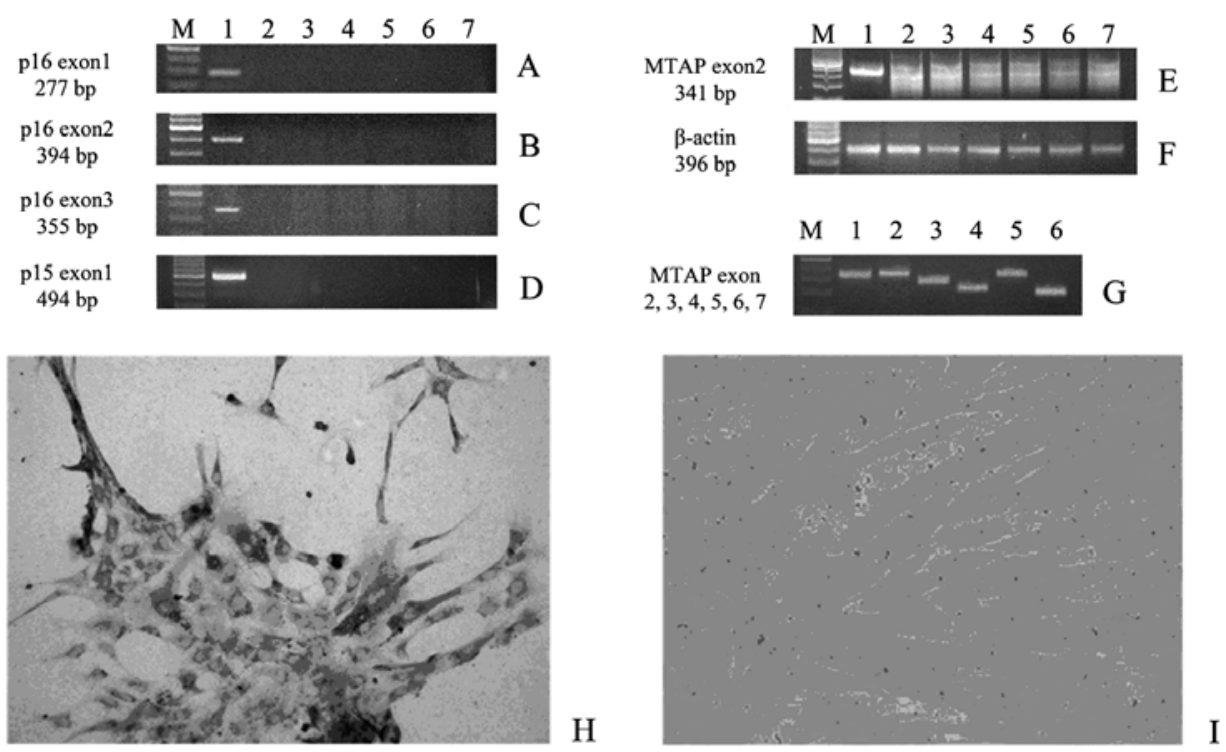

Figure 1. Interstitial deletions of 9p21. (A) Homozygous deletion of the p16 exon 1, (B) exon 2, (C) exon 3 and (D) p15 exon 1 in 6 hEMTCs. (E) PCR products of exon 2 of MTAP. (F) The internal control of $\beta$-actin. Lanes 1-8 from left to right, 100 bp ladder, the normal control, MS0812, MS0504, M3, M4, M5B, M5C (A-F). (G) Positive control of MTAP: lanes 1-7 from left to right, 100 bp ladder, exons 2-7 of MTAP in normal human embryonic muscle cells. (H) p16 protein expression. The normal embryonic muscle cells were positive for p16 staining in cytoplasm. (I) hEMTCs (M3, standing for 6 cell lines) were negative for $p 16$.

PCR products was performed on a $2 \%$ agarose gel subsequently stained with ethidium bromide and photographed.

$R T$-PCR for $p 21$ and $p 53$. Total RNA was isolated using TRIzol Reagent (Invitrogen) following the recommendations of the manufacturer. cDNA from each cell line was synthesized from denatured RNA $\left(65^{\circ} \mathrm{C}\right.$ for $\left.5 \mathrm{~min}\right)$ by incubation at $42^{\circ} \mathrm{C}$ for $60 \mathrm{~min}$ with final quantities or concentrations of $3 \mu \mathrm{l}$ of $100 \mathrm{ng} / \mu \mathrm{l}$ oligo (dT), $2 \mu \mathrm{l}$ of $50 \mathrm{U} / \mu 1$ StrataScript reverse transcriptase, $1 \mu 1$ of $40 \mathrm{U} / \mu 1$ RNase Ribonuclease inhibitor (Takara, Dalian), and $4 \mu 110 \mathrm{mM}$ dNTP mixture. Primers used for $p 21$ and $p 53$ of RT-PCR are summarized in Table I, $\beta$-actin was used for RT-PCR control. All RT-PCRs were carried out in a 50X PCR reaction containing $0.4 \mathrm{mM}$ each primer, 5 units of Takara Taq, $1.5 \mathrm{mM} \mathrm{MgCl}_{2}, 4 \mu \mathrm{l}$ $10 \mathrm{mM}$ dNTP Mixture. The reaction conditions are shown in Table I.

DNA sequencing. The PCR products of exons 7,8 and intron 7 of $p 53$ and RT-PCR products of $p 21$ were sequenced directly by Shanghai Sangon Biological Engineering Technology \& Services Co,. Ltd. (11). The sequence equipment was ABI PRISM 3730. BigDye terminator was used for sequence reagent. All samples were tested by simultaneous bi-directional sequencing (Table II).

Immunocytochemistry. MS0812, MS0504, M3, M4, M5B and M5C were cultured in 3.5-cm dishes, and at 80-90\% confluence, they were fixed with $4 \%$ paraformaldehyde for $15 \mathrm{~min}$, followed by washing in phosphate-buffered saline (PBS) 3 times, each $2 \mathrm{~min}$, endogenous peroxidase activity were quenched in $3 \% \mathrm{H}_{2} \mathrm{O}_{2}$ for $15 \mathrm{~min}$, then were permeated in $0.25 \%$ Triton $\mathrm{X}-100$ for $15 \mathrm{~min}$. The anti-p16 antibody (Zymed, Beijing) was applied at 1:50 dilutions in PBS and incubated in a humidity chamber at room temperature for $2 \mathrm{~h}$.
The secondary antibody staining kit was SP-9000 of broad spectrum provided by the Zhongshan Jinqiao Company, Beijing. AEC served as chromagen. Next, the samples were observed under a powerful optical microscope (x40).

\section{Results}

Homozygous deletions within chromosome bands 9p21 which included p16, p15 and MTAP. To assess the status of $p 16$ in our cell lines, we used PCR assays in which p16 exons 1-3 fragments were amplified from genomic DNA. No p16 (including exons 1-3) specific product was detected in the 6 hEMTCs. However, specific PCR products using genomic DNA from normal embryonic muscle cells were detected (Fig. 1A-C). p15 and MTAP also locate at chromosome bands $9 \mathrm{p} 21$, and their status were assessed, the results showed that $p 15$ exon 1 (Fig. 1D) and exons 3-7 of MTAP (data not shown) were deleted in the 6 cell lines, while the normal control showed specific products (Fig. 1G). Nevertheless, an amplifications of MTAP exon 2 showed several non-specific bands in the 6 hEMTCs, but the positive control of normal embryonic muscle cells showed only one specific band in the same reaction system (Fig. 1E). $\beta$-actin was used for internal control and could be detected in all PCRs from the 6 cell lines (Fig. 1F). We performed immunostaining for $p 16$ and found out that the 6 hEMTCs were negative (Fig. 1I), the normal embryonic muscle cells showed positive staining in the cytoplasm (Fig. 1H).

Sequence of p53 exons 7, 8 and intron 7. The PCR products of p53 exons 7, 8 and intron 7 were successfully amplified, and we sequenced the $6 \mathrm{hEMTCs}$ (MS0812, MS0504, M3, M4, M5B and M5C) and found that $p 53$ in the 6 hEMTCs had a wide range of change, and the mutations were complicated. All 6 hEMTCs exhibited the same mutation 


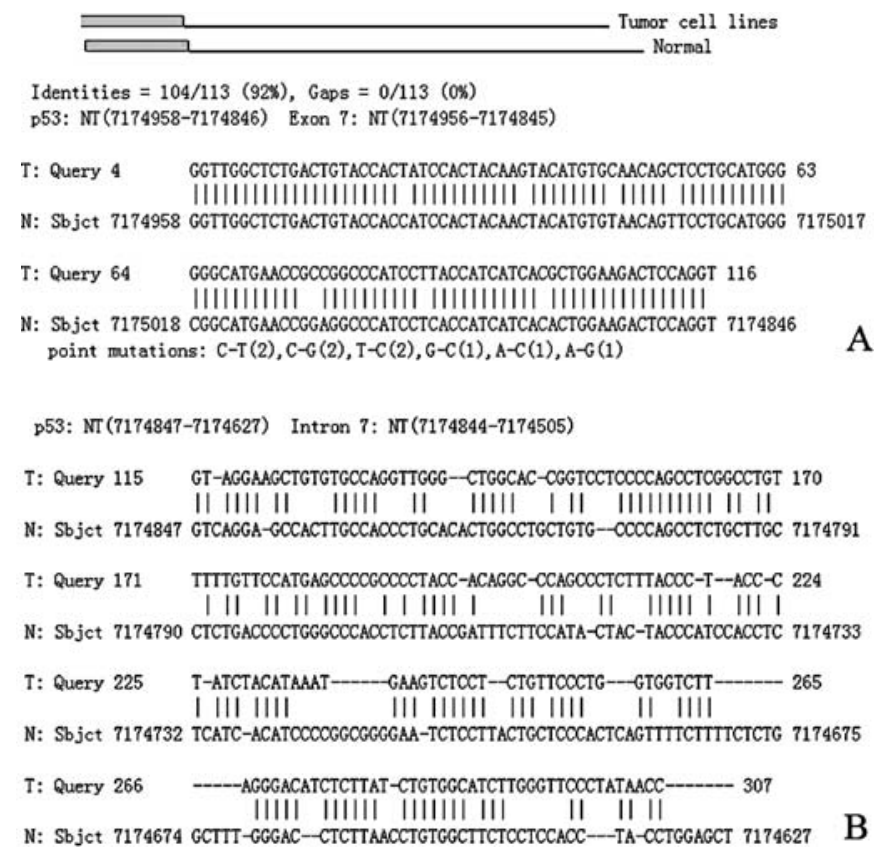

p53: NT(7174626-7174509) Intron 7: NT(7174844-7174505)

T: Query 308 GGAGCTTCA-GCTCCAGATAGGACAGGGG-AGTTGGGAACAGGTAGG-GCCTGG---TT 361 |IIIII| | |IIIIIII |IIIIIII || |IIIII| || | || |IIII| || N: Sbjct 7174626 GGAGCTT-AGGCTCCAGAAGGACAAG-GGTGGTTGGGAGTAGAT-GGAGCCTGGTTITT 7174570

T: Query 362 TACAGTCAGGA-TGG-A-GCCCAGCTTT-CTTACTGCCT-TGTGCTGTGC-CTCCTCTTG 415 |I | | |II || | | || | |I| |IIIIIIII| | |II| | | || || |

N: Sbjct 7174569 TA-AAT-GGGACAGGTAGGACCTGATTTCCTTACTGCCTCT-TGCT-T-CTCTITTCCTA 7174515

T: Query 416 TCCCGG 421

T: Query 416 III I

N: Sbjct 7174514 TCCTGA 7174509

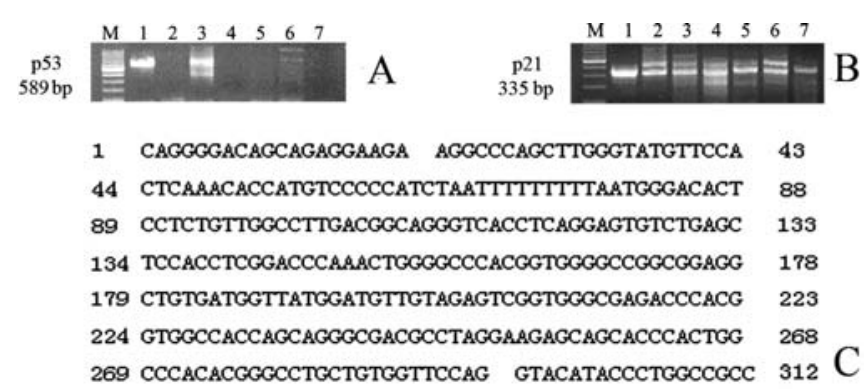

58
C C C C C ATCTAATTTTTTTTA ATGGGACACTCCTCTGTT

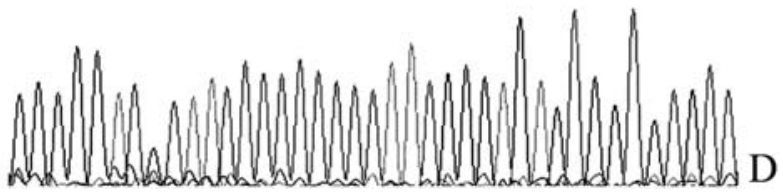

Figure 3. The transcription of $p 21$ and p53 in 6 hEMTCs. (A) RT-PCR products of p53 and (B) p21 in $6 \mathrm{hEMTCs}$ (lanes 2-8 from left to right, normal human embryonic muscle cells, MS0812, MS0504, M3, M4, M5B and M5C). (C) p21 cDNA sequence and (D) sequence mapping of line M3 ranged from NT 27510435 to NT 27510573; NT 27511778 to NT 27511973 in Genebank.

since the structure was changed significantly and BLAST could not be aligned (Fig. 2D).

p53 and p21 of RT-PCR and DNA sequencing of p21. We assayed the transcription of $p 53$ in 6 hEMTCs and only M3 showed the $p 53$ transcription (Fig. 3A). The transcription of $p 21$ in the 6 hEMTCs was also assayed using the RTPCR. All 6 hEMTCs showed transcription product of $p 21$ but with a non-specific band of about $450 \mathrm{bp}$ in line MS0812, MS0504, M3, M4, M5B (Fig. 3B), while the normal control showed only one specific band in the same PCR conditions (Fig. 3B). The RT-PCR products of $p 21$ in 6 hEMTCs and normal control were sequenced, and only M3 could be sequenced totally. The expected length was $335 \mathrm{bp}$, and the real length was $312 \mathrm{bp}$, the sequence was totally changed and had no similarity to the wt p21 (Fig. 3C), and the sequence signal was specific (Fig. 3D). However, the control (normal human embryonic muscle cells) was the same as $w t$ p 21 sequence (data not shown). The other 5 hEMTCs could only be sequenced partly, and the sequenced $180 \mathrm{bp}$ was about the same as corresponding M3 (data not shown). The $p 21$ (RT-PCR) sequence of line M3 (Fig. 3C) exhibited sequential nucleotide ' $\mathrm{T}$ ' and rich ' $\mathrm{GC}$ ' regions, these special structures could lead to the weak sequence signal which make the sequencing impossible. Therefore, we got one complete result.

\section{Discussion}

At present, the reports on malignant transformation of cultured human cells in vitro are rare $(6-9,12,13)$, while malignant transformation in vitro could be observed in embryonic cells from mice (14-16). One hypothesis to explain this phenomenon is that the number of mutational events sequence (from NT 7174626 to 7174509 ) (Fig. 2C), and the rest (from NT 7174847 to 7174627 ) was aligned manually model. Exons 7 and 8 of $p 53$ which compared to the wt $p 53$ frequency of mutations which reaching as high as $8 \%$ (Fig. 2A) and $14 \%$ (Fig. 2B), respectively. All of them were point mutations. The intron 7 changed more significantly, including piece deletion, insertions, frameshift and point owed almost no similarity to the $w t$ p sequence, and we could only use BLAST (Basic Loca Alignment Search Tool) for comparing part of the intron 7 
Table II. TP53 mutations of exons 7 and 8 in 6 hEMTCs.

\begin{tabular}{|c|c|c|c|c|}
\hline $\begin{array}{l}\text { Location } \\
\text { (codon) }\end{array}$ & Nucleotide substitution & Mutation effect & Frequency & Mutation recorded \\
\hline \multicolumn{5}{|l|}{ Exon 7} \\
\hline 231 & $\mathrm{C} \rightarrow \mathrm{T}(\mathrm{ACC} \rightarrow \mathrm{ACT})$ & Thr (synonymous) & 7 & No \\
\hline 235 & $\mathrm{C} \rightarrow \mathrm{G}(\mathrm{AAC} \rightarrow \mathrm{AAG})$ & Asn to Lys (missense) & 0 & No \\
\hline 238 & $\mathrm{~T} \rightarrow \mathrm{C}(\mathrm{TGT} \rightarrow \mathrm{TGC})$ & Cys (synonymous) & 4 & No \\
\hline 240 & $\mathrm{~T} \rightarrow \mathrm{C}(\mathrm{AGT} \rightarrow \mathrm{AGC})$ & Ser (synonymous) & 9 & No \\
\hline 244 & $\mathrm{C} \rightarrow \mathrm{G}(\mathrm{GGC} \rightarrow \mathrm{GGG})$ & Gly (synonymous) & 21 & No \\
\hline 248 & $\mathrm{G} \rightarrow \mathrm{C}(\mathrm{CGG} \rightarrow \mathrm{CGC})$ & Arg (synonymous) & 3 & No \\
\hline 249 & $\mathrm{~A} \rightarrow \mathrm{C}(\mathrm{AGG} \rightarrow \mathrm{CGG})$ & Arg (synonymous) & 6 & No \\
\hline 252 & $\mathrm{C} \rightarrow \mathrm{T}(\mathrm{CTC} \rightarrow \mathrm{CTT})$ & Leu (synonymous) & 8 & No \\
\hline 256 & $\mathrm{~A} \rightarrow \mathrm{G}(\mathrm{ACA} \rightarrow \mathrm{ACG})$ & Thr (synonymous) & 4 & No \\
\hline \multicolumn{5}{|l|}{ Exon 8} \\
\hline 262 & $\mathrm{~T} \rightarrow \mathrm{G}(\mathrm{GGT} \rightarrow \mathrm{GGG})$ & Gly (synonymous) & 3 & No \\
\hline 264 & $\mathrm{~A} \rightarrow \mathrm{T}(\mathrm{CTA} \rightarrow \mathrm{CTT})$ & Leu (synonymous) & 7 & No \\
\hline 268 & $\mathrm{~A} \rightarrow \mathrm{G}(\mathrm{AAC} \rightarrow \mathrm{GAC})$ & Asn to Asp (missense) & 0 & No \\
\hline 272 & $\mathrm{G} \rightarrow \mathrm{T}(\mathrm{GTG} \rightarrow \mathrm{GTT})$ & Val (synonymous) & 11 & No \\
\hline 282 & $\mathrm{G} \rightarrow \mathrm{T}(\mathrm{CGG} \rightarrow \mathrm{CGT})$ & Arg (synonymous) & 7 & No \\
\hline 283 & $\mathrm{C} \rightarrow \mathrm{G}(\mathrm{CGC} \rightarrow \mathrm{CGG})$ & Arg (synonymous) & 10 & No \\
\hline 287 & $\mathrm{G} \rightarrow \mathrm{A}(\mathrm{GAG} \rightarrow \mathrm{GAA})$ & Glu (synonymous) & 8 & No \\
\hline 289 & $\mathrm{C} \rightarrow \mathrm{T}(\mathrm{CTC} \rightarrow \mathrm{TTC})$ & Leu to Phe (synonymous) & 4 & Infrequent \\
\hline 291 & $\mathrm{G} \rightarrow \mathrm{A}(\mathrm{AAG} \rightarrow \mathrm{AAA})$ & Lys (synonymous) & 4 & No \\
\hline 293 & $\mathrm{G} \rightarrow \mathrm{A}(\mathrm{GGG} \rightarrow \mathrm{GAA})$ & Gly to Glu (missense) & 0 & In skin cancer \\
\hline 295 & $\mathrm{C} \rightarrow \mathrm{A}(\mathrm{CCT} \rightarrow \mathrm{CAT})$ & Pro to His (missense) & 2 & Infrequent \\
\hline 296 & $\mathrm{C} \rightarrow \mathrm{T}, \mathrm{A} \rightarrow \mathrm{G}(\mathrm{CAC} \rightarrow \mathrm{TGC})$ & His to Cys (missense) & 0 & In skin cancer \\
\hline 297 & $\mathrm{~A} \rightarrow \mathrm{C}, \mathrm{C} \rightarrow \mathrm{G}(\mathrm{CAC} \rightarrow \mathrm{CCG})$ & His to Pro (missense) & 2 & In skin cancer \\
\hline 303 & $\mathrm{C} \rightarrow \mathrm{T}(\mathrm{AGC} \rightarrow \mathrm{AGT})$ & Ser (synonymous) & 2 & No \\
\hline 304 & $\mathrm{~A} \rightarrow \mathrm{G}, \mathrm{T} \rightarrow \mathrm{A}(\mathrm{ACT} \rightarrow \mathrm{GCA})$ & Thr to Ala (missense) & 4 & In skin cancer \\
\hline 306 & $\mathrm{C} \rightarrow \mathrm{A}(\mathrm{CGA} \rightarrow \mathrm{AGA})$ & Arg (synonymous) & 2 & No \\
\hline
\end{tabular}

Frequency, the mutation frequency on this codon location which has been published. Mutation recorded, this mutation type which has been described in UMD p53 database (http://www.umd.be:2072/).

required to confer immortality on rodent cells is fewer than the number required for human and avian cells (or the rates of mutation are different) (17). Consequently, no one human or avian cell can acquire all of the alterations necessary for indefinite growth before the onset of the crisis period (17). Recent research has shown that mesenchymal stem cells from human (6-8) or mice (18-20) which were cultured for long-term in vitro could transform malignantly, the mechanism underlying it is not clear yet. It might be associated with the activation of oncogenes and inactivation of tumor suppressor genes, such as the amplification of $c$-myc and the inactivation of $C D K I$ family $(6,8,14,21)$. We found that human embryonic muscle cells cultured in vitro long-term could become immortalized spontaneously, and have obtained 6 novel cell lines (10). This type of tumor cell lines expressed actin, vimentin and desmin in vitro, which suggest that these malignant cells were originated from embryonic muscle cells, and these cell lines could develop sarcoma in nude mice (10). However, malignant transformation mechanism in gene level is not clear yet. The goal of this study was to determine if several classic tumor suppressor genes such as $p 53, p 21$ and $p 16$ have an effect on the malignant transformation of embryonic muscle cells.

The interstitial deletions of the 9p21 were observed in a variety of tumor types, including acute lymphoblastic leukemia, glioma, melanoma, lung cancer, head and neck cancer, mesothelioma, ovarian cancer and bladder cancer (22-25). As CDKI family (including $p 16, p 15$, and $p 21$ ) play the predominant role in both $p 53$ and $p R b$ pathways, the inactivation of these tumor suppressor genes in this region, also including MTAP (methylthioadenosine phosphorylase), contributes to the malignant process in all these different tumor types $(26,27)$. CDKN2A generates several transcript variants which differ in their first exons, two of which encode structurally related isoforms known to function as inhibitors of CDK4 kinase (p16). The remaining transcript (CDKN2A $A^{A R F}$; also called $p 14$ ) is an alternate open reading frame (ARF) that specifies a protein which is structurally unrelated to the 
products of the other variants. Because deletion of the $p 16$ and $p 14$ causes dysregulation of the $p 53$ and $p R b$ pathways in most cancers, loss of MTAP activity is thought to be incidental and not of pathogenic consequence (28). However, in certain cancers, loss of MTAP has been observed in cells that retain $p 16$. In a study of non-small cell lung cancer, homozygous deletion of MTAP occurred in 38\% (19 of 50) of the samples compared with only $18 \%$ (9 of 50) for $p 16$ (30). The fact that MTAP is lost independently of p16 hints that loss of MTAP may have some functional basis in tumor biology (29-31).

We assayed the status of tumor suppressor genes $p 16, p 15$ and MTAP which located at 9p21 in the hEMTCs, and all 3 genes were deleted in these cell lines. This suggested that the interstitial deletion of $9 \mathrm{p} 21$ existed in this new type of sarcoma cell line as reported of adult human spontaneous transformed stem cells (6). The PCR products of exon 2 of MTAP showed some non-specific amplification and weak purpose band, this suggested that there may be a breakpoint near this location. This result was partly consistent with the report that a frequent breakpoint took place between MTAP exon 4 and exon 5 (30).

The p53 tumor suppressor gene is mutated in over $50 \%$ of human cancers, $74 \%$ of these mutations are missense, which result in full-length, albeit mutant, proteins. This fraction of missense mutations is much higher than in other tumor suppressor genes (32) and implies that p53 mutant proteins confer some selective advantage in carcinogenesis. It has been shown previously that mutant $p 53$ can act as an immortalizing gene when cotransfected into primary rat embryo fibroblasts along with a selectable marker (17), but whether this protocol works in human embryonic cells is not clear yet. Human adult spontaneous transformed stem cells were identified with $p 53$ inactivation by RT-PCR, but detailed information on p53 was not documented (6). To determine whether a mutation at the p53 locus is a common event in the pathways leading to spontaneous cellular immortalization, 6 malignant transformed cell lines were examined for $p 53$ alterations by PCR and DNA sequencing. We checked the mutations of our cell lines on the UMD TP53 mutation database (http://www.umd.be:2072/). This is one of the two most regularly updated databases for TP53 mutations, the other one is the International Agency for Research on Cancer (IARC) database (http://www.p53.iarc.fr/index.html/). Our results were totally different from the $p 53$ mutation database published (30-33). In particular, the sequence of intron 7 of p53 in our hEMTCs is completely altered, this is different from the mutation type of $p 53$ which is mainly point mutation in malignant cells (37-42). The alterations of $p 53$ codon region will definitely change the transcription and expression of $p 53$ protein in hEMTCs. The new gain of function of mutant $p 53$ protein was able to play a role in the malignant transformation process. All our sequencing results of p53 (exons 7,8 and intron 7) in 6 cell lines show high consistency which suggested that a common mutation mechanism and strong selective advantage over long-term culture. The transcription of $p 53$ and $p 21$ in 6 hEMTCs was also tested using the normal primer sequence (Table I), and only M3 showed $p 53$ transcription. The negative results in the other 5 hEMTCs indicated no $p 53$ transcription, the reason for this was not clear, p53 complicated alterations may account for this negative result, as indicated by exons 7 , 8 and intron 7 sequencing results.

We sequenced all the products (normal control and 6 hEMTCs) and found out that the sequence of the $6 \mathrm{hEMTCs}$ was aberrant comparing with the wt p21 sequence of normal control (335 bp, from NT 27510435 to NT 27510573; NT 27511778 to NT 27511973). We obtained one complete sequence of $312 \mathrm{bp}$ from line M3 in which the sequence mapping was specific and credible (Fig. 3C and D). The reason why the transcription of $p 21$ changed so much needs further research.

In summary, spontaneous hEMTCs in vitro exhibit the interstitial deletions of the $9 \mathrm{p} 21$ which include MTAP, p16 and $p 15, p 53$ also changed significantly, the mutation mode in exons 7,8 was point mutation, while intron 7 aberration was complex, including point mutations, fragment deletions and insertions. Our sequencing results of $6 \mathrm{hEMTCs}$ (including 5 different genetic backgrounds) showed high identity in mutation mode, which suggests this mutation mode is common in our hEMTCs and has a strong selective advantage over long-term culture. The aberration and inactivation of tumor suppressor genes which include $p 53, p 21$, p16, p14, p15 and MTAP permits DNA-damaged cells to continue replicating, this frequently contributes to the accumulation of gene mutations and plays an important role in the malignant transformation process.

\section{Acknowledgements}

This study was supported by The National Natural Science Foundation of China (No. 30672359) and Social Development Program of Guangdong Province (2005B34001009).

\section{References}

1. Huang PS and Heimbrook DC: Oncogene products as therapeutic targets for cancer. Curr Opin Oncol 9: 94-100, 1997.

2. Schinzel AC and Hahn WC: Oncogenic transformation and experimental models of human cancer. Front Biosci 13: 71-84, 2008.

3. Skapek SX, Pan YR and Lee EY: Regulation of cell lineage specification by the retinoblastoma tumor suppressor. Oncogene 25: 5268-5276, 2006.

4. Li Y, Nichols MA, Shay JW and Xiong Y: Transcriptional repression of the D-type cyclin-dependent kinase inhibitor p16 by the retinoblastoma susceptibility gene product $\mathrm{pRb}$. Cancer Res 54: 6078-6082, 1994.

5. Bourdon JC: p53 and its isoforms in cancer. Br J Cancer 97: 277-282, 2007.

6. Rubio D, Garcia S, Paz MF, De la Cueva T, LopezFernandez LA, Lloyd AC, Garcia-Castro J and Bernad A: Molecular characterization of spontaneous mesenchymal stem cell transformation. PLoS ONE 3: e1398, 2008.

7. Xu W, Qian H, Zhu W, Chen Y, Shao Q, Sun X, Hu J, Han C and Zhang X: A novel tumor cell line cloned from mutated human embryonic bone marrow mesenchymal stem cells. Oncol Rep 12: 501-508, 2004.

8. Rubio D, Garcia-Castro J, Martín MC, de la Fuente R, Cigudosa JC, Lloyd AC and Bernad A: Spontaneous human adult stem cell transformation. Cancer Res 65: 3035-3039, 2005.

9. Gibbs CP, Kukekov VG, Reith JD, Tchigrinova O, Suslov ON, Scott EW, Ghivizzani SC, Ignatova TN and Steindler DA: Stem-like cells in bone sarcomas: implications for tumorigenesis. Neoplasia 7: 967-976, 2005.

10. Yang L, Chen Q, Zhang S, Wang X, Li W, Wen J, Huang X, Zheng J, Huang G, Huang T and Ju G: A novel mutated cell line with characteristics of dedifferentiated chondrosarcoma. Int J Mol Med 24: 427-435, 2009. 
11. Nagahashi M, Ajioka Y, Lang I, Szentirmay Z, Kasler M, Nakadaira H, Yokoyama N, Watanabe G, Nishikura K, Wakai T, Shirai Y, Hatakeyama K and Yamamoto M: Genetic changes of p53, K-ras, and microsatellite instability in gallbladder carcinoma in high-incidence areas of Japan and Hungary. World J Gastroenterol 14: 70-75, 2008.

12. Bernardo ME, Zaffaroni N, Novara F, Cometa AM, Avanzini MA, Moretta A, Montagna D, Maccario R, Villa R, Daidone MG, Zuffardi $\mathrm{O}$ and Locatelli F: Human bone marrow derived mesenchymal stem cells do not undergo transformation after longterm in vitro culture and do not exhibit telomere maintenance mechanisms. Cancer Res 67: 9142-9149, 2007.

13. Riggi N, Cironi L, Provero $\mathrm{P}$, Suvà ML, Kaloulis K, GarciaEcheverria C, Hoffmann F, Trumpp A and Stamenkovic I: Development of Ewing's sarcoma from primary bone marrowderived mesenchymal progenitor cells. Cancer Res 65: 11459$11468,2005$.

14. Todaro GJ and Green H: Quantitative studies of the growth of mouse embryo cells in culture and their development into established lines. Cell Biol 17: 299-313, 1963.

15. Meek RL, Bowman PD and Daniel CW: Establishment of rat embryonic cells in vitro. Relationship of DNA synthesis, senescence, and acquisition of unlimited growth potential. Exp Cell Res 127: 127-132, 1980

16. Curatolo L, Erba E and Morasca L: Culture conditions induce the appearance of immortalized $\mathrm{C} 3 \mathrm{H}$ mouse cell lines. In Vitro 20: 597-601, 1984 .

17. Harvey DM and Levine AJ: p53 alteration is a common event in the spontaneous immortalization of primary $\mathrm{BALB} / \mathrm{c}$ murine embryo fibroblasts. Genes Dev 5: 2375-2385, 1991.

18. Miura M, Miura Y, Padilla-Nash HM, Molinolo AA, Fu B, Patel V, Seo BM, Sonoyama W, Zheng JJ, Baker CC, Chen W, Ried T and Shi S: Accumulated chromosomal instability in murine bone marrow mesenchymal stem cells leads to malignant transformation. Stem Cells 24: 1095-1103, 2006.

19. Aguilar S, Nye E, Chan J, Loebinger M, Spencer-Dene B, Fisk N, Stamp G, Bonnet D and Janes SM: Murine but not human mesenchymal stem cells generate osteosarcoma-like lesions in the lung. Stem Cells 25: 1586-1594, 2007.

20. Tolar J, Nauta AJ, Osborn MJ, Panoskaltsis Mortari A, McElmurry RT, Bell S, Xia L, Zhou N, Riddle M, Schroeder TM, Westendorf JJ, McIvor RS, Hogendoorn PC, Szuhai K, Oseth L, Hirsch B, Yant SR, Kay MA, Peister A, Prockop DJ, Fibbe WE and Blazar BR: Sarcoma derived from cultured mesenchymal stem cells. Stem Cells 25: 371-379, 2007.

21. Fujii H, Honoki K, Tsujiuchi T, Kido A, Yoshitani K, Mori T and Takakura Y: Reduced expression of INK4a/ARF genes in stem-like sphere cells from rat sarcomas. Biochem Biophys Res Commun 362: 773-778, 2007.

22. Olopade OI, Buchhagen DL, Malik K, Sherman J, Nobori T, Bader S, Nau MM, Gazdar AF, Minna JD and Diaz MO: Homozygous loss of the interferon genes defines the critical region on 9p that is deleted in lung cancers. Cancer Res 53: 2410-2415, 1993

23. Cheng JQ, Jhanwar SC, Lu YY and Testa JR: Homozygous deletions within 9p21-p22 identify a small critical region of chromosomal loss in human malignant mesotheliomas. Cancer Res 53: 4761-4763, 1993.

24. Stadler WM and Olopade OI: The 9p21 region in bladder cancer cell lines: large homozygous deletion inactivate the $C D K N 2$, $C D K N 2 B$ and MTAP genes. Urol Res 24: 239-244, 1996.

25. Worsham MJ, Chen KM, Tiwari N, Pals G, Schouten JP, Sethi S and Benninger MS: Fine-mapping loss of gene architecture at the $C D K N 2 B(p 15 I N K 4 b), C D K N 2 \mathrm{~A}(p 14 A R F, p 16 I N K 4 a)$, and $M T A P$ genes in head and neck squamous cell carcinoma. Arch Otolaryngol Head Neck Surg 132: 409-415, 2006.
26. Knudsen ES and Knudsen KE: Retinoblastoma tumor suppressor: where cancer meets the cell cycle. Exp Biol Med 231: 1271-1281, 2006.

27. Kovar H, Jug G, Aryee DN, Zoubek A, Ambros P, Gruber B, Windhager R and Gadner $\mathrm{H}$ : Among genes involved in the RB dependent cell cycle regulatory cascade, the p16 tumor suppressor gene is frequently lost in the Ewing family of tumors. Oncogene 15: 2225-2232, 1997.

28. Nobori T, Takabayashi K, Tran P, Orvis L, Batova A, Yu AL and Carson DA: Genomic cloning of methylthioadenosine phosphorylase: a purine metabolic enzyme deficient in multiple different cancers. Proc Natl Acad Sci USA 93: 6203-6208, 1996.

29. Christopher SA, Diegelman P, Porter CW and Kruger WD: Methylthioadenosine phosphorylase, a gene frequently codeleted with $\mathrm{p} 16(\mathrm{cdkN} 2 \mathrm{a} / \mathrm{ARF})$, acts as a tumor suppressor in a breast cancer cell line. Cancer Res 62: 6639-6644, 2002.

30. Schmid M, Malicki D, Nobori T, Rosenbach MD, Campbell K, Carson DA and Carrera CJ: Homozygous deletions of methylthioadenosine phosphorylase $(M T A P)$ are more frequent than p16INK4A (CDKN2) homozygous deletions in primary nonsmall cell lung cancers (NSCLC). Oncogene 17: 2669-2675, 1998.

31. García-Castellano JM, Villanueva A, Healey JH, Sowers R, Cordon-Cardo C, Huvos A, Bertino JR, Meyers P and Gorlick R: Methylthioadenosine phosphorylase gene deletions are common in osteosarcoma. Clin Cancer Res 8: 782-787, 2002.

32. Hussain SP and Harris CC: Molecular epidemiology of human cancer: contribution of mutation spectra studies of tumor suppressor genes. Cancer Res 58: 4023-4037, 1998.

33. Beroud C and Soussi T: $p 53$ gene mutation: software and database. Nucleic Acids Res 26: 200-204, 1998.

34. Cariello NF, Beroud C and Soussi T: Database and software for the analysis of mutations at the human $p 53$ gene. Cancer Res 54: 4454-4460, 1994.

35. Hainaut P, Hernandez T, Robinson A, Rodriguez-Tome P, Flores T, Hollstein M, Harris CC and Montesano R: IARC database of $p 53$ gene mutations in human tumors and cell lines: updated compilation, revised formats and new visualisation tools. Nucleic Acids Res 26: 205-213, 1998.

36. Hamroun D, Kato S, Ishioka C, Claustres M, Béroud $C$ and Soussi T: The UMD TP53 database and website: update and revisions. Hum Mutat 27: 14-20, 2006.

37. Liu Y and Bodmer WF: Analysis of p53 mutations and their expression in 56 colorectal cancer cell lines. Proc Natl Acad Sci USA 103: 976-981, 2006.

38. Nigro JM, Baker SJ, Preisinger AC, et al: Mutations in the $p 53$ gene occur in diverse human tumour types. Nature 342: 705-708, 1989.

39. Albor A, Flessate DM, Soussi T and Notario V: 3-Methylcholanthrene inactivates the $p 53$ gene in syrian hamster embryo fibroblasts by inducing a specific intronic point mutation. Cancer Res 54: 4502-4507, 1994.

40. Das P, Kotilingam D, Korchin B, Liu J, Yu D, Lazar AJ, Pollock RE and Lev D: High prevalence of p53 exon 4 mutations in soft tissue sarcoma. Cancer 109: 2323-2333, 2007.

41. Cordon-Cardo C, Latres E, Drobnjak M, Oliva MR, Pollack D, Woodruff JM, Marechal V, Chen J, Brennan MF and Levine AJ: Chromosome 17 abnormalities and TP53 mutations in adult soft tissue sarcomas. Am J Pathol 145: 345-355, 1994.

42. Li H, Fan X, Kovi RC, Jo Y, Moquin B, Konz R, Stoicov C, Kurt-Jones E, Grossman SR, Lyle S, Rogers AB, Montrose M and Houghton J: Spontaneous expression of embryonic factors and $p 53$ point mutations in aged mesenchymal stem cells: a model of age-related tumorigenesis in mice. Cancer Res 67: 10889-10898, 2007. 